\title{
THE IMPLEMENTATION OF SIMPLE PRESENT VERB AND VOCABULARY MASTERY IN TEACHING WRITING DESCRIPTIVE TEXT
}

\author{
Kartika Zakiah Darajat \\ English Education Program-Postgraduate Faculty \\ Universitas Indraprasta PGRI, Jakarta \\ Email: hidayat.kartika@gmail.com
}

\begin{abstract}
The research aims to understand the effects of simple present verb and vocabulary mastery on students' writing skills in the descriptive text at state vocational high schools in Tangerang Regency. The method used in this research is a survey method. The research shows: There are any significant effects of simple present verb mastery and vocabulary mastery jointly towards students' writing skill in descriptive Text at State Vocational High Schools in Tangerang Regency. It is proved by the result value $\mathrm{Sig}=0,000<0,05$ and F observed $=191,873$. It can be concluded that the simple present verb variable and vocabulary significantly influence students' writing skills in the descriptive text at state vocational high schools in Tangerang Regency.

Keywords: simple present verb mastery, vocabulary mastery, students' writing skill in descriptive text.
\end{abstract}

\section{Introduction}

Language is vital in human life; people use language for communication between one and another. Language is also used to deliver messages or ideas from the speaker to the listener in interaction among themselves or with the environment. Without language, people or everyone cannot interact with each other in daily life or learn something. Human activities could not run without language. Every country has a different language, and we need an international language for communication around the world. Every country has its language, such as Spain has Spanish, France has French, England has English, Malaysia has Malay, and Indonesia has Bahasa Indonesia. Because of the various languages, people need a language that can be universally used, which is called international language. The language that acts as an international language is English. In many countries in the world that do not have English as the mother tongue, study English as the second language, and English is used in many fields of life. As English becomes the language for international communication, more people use English for various purposes. English is used for academic purposes, tourism, entertainment, business and finance, information, political, interpersonal relationships, social and education, and many other international purposes. Therefore, English as a language in international communication is needed by many learners to deliver thoughts or ideas in various situations.

Language promotes some skills. People must learn to achieve integrated language skills. If someone wants to learn English well, they should know four skills. Four skills in English have to be mastered by students as the goal of teaching and learning English. They are speaking, reading, listening, and writing, which the students should master. One of the skills learned at school is writing. Writing is a psychological activity of the language used to put information in the writing text.

Nowadays, written English that is taught in schools in Indonesia focuses on text genre. Students study the text genre or text in junior and vocational high school/ senior high schools. They are Narration, Description, Exposition, Argumentation, and Persuasion. In this study, the writer focuses on descriptive text. The descriptive text is studied by the first-year students at a vocational high school in their first semester. 
In order to be able to write or make a composition clearly and correctly in English, especially in writing descriptive text, students have to be supported by the mastery of two critical subsystems or components of language, namely vocabulary and grammar at once. In other than that, teaching and learning English as a foreign language need grammar to speak and write correctly.

Thus, the writer tried to connect both, especially writing a descriptive text. The writer also wanted to determine the level of students' ability to learn vocabulary and writing. And then, in teaching and learning English as a foreign language, it needs grammar to speak and write correctly. The students need grammar to make a good sentence. Grammar is also called organization words combined into sentences to express thought and feeling or express the idea in writing. In mastering English grammar, there are many rules and sentences that the students should master. One of the sentences is simple present tense, that one of the language features of writing descriptive text. Based on the background above, the writer wants to research the title: The Effects of Simple Present Verb and Vocabulary Mastery Towards Students' Writing Skill in Descriptive Text (Survey at State Vocational High Schools in Tangerang Regency).

\section{Research Methods}

In this research, the researcher used the survey method, and the survey method has the purpose "to interpret the characteristics of the whole population accurately" (Kerlinger, 2003:661). Furthermore, Creswell (2014: 201) stated that "A survey design provides a quantitative or numeric description of trends, attitudes, or opinions of a population by studying a sample of that population. From sample results, the researcher generalizes or draws inferences to the population".

The outline of steps for a survey study began with "a discussion about the purpose, the identification of the population and sample, the survey instruments to be used, the relationship between the variables, the research questions, specific items on the survey, and steps to be taken in the analysis and the interpretation of the data from the survey" (Creswell: 228).

The researcher used the survey method. There are three variables, and there are two independent variables and one dependent variable. The independent variables are Simple Present Verb Mastery (X1) and Vocabulary Mastery (X2). The dependent variable of this research is Student's Writing Descriptive Text (Y). The research was done for four months, start in August 2019 to January 2020. In this research, the researcher took a sample of 72 students and chose one class from each school consisting of 36 students each class in AKL competency from both schools. This sample has fulfilled the minimum number of participants that should be assigned in a survey study. The relation between the variables can be explained as a picture below:

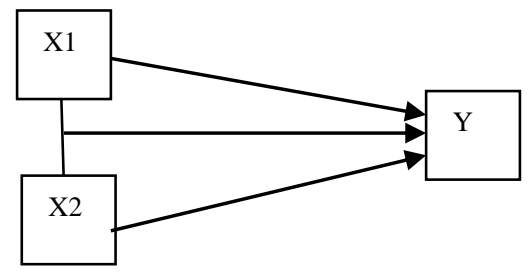

Figure 1. The Constellation the Problem of the Research

Note:

X1: Simple Present Verb Mastery

X2: Vocabulary Mastery

Y: Students' Writing Skill in Descriptive Text

The techniques of collecting data that are used in this study are:

1. Data about simple present verb mastery on this research is taken from a specific grammar test, especially the simple present verb. 
INFERENCE: Journal of English Language Teaching

Vol. 4, No. 1, April - July 2021

p-ISSN: 2615-8671

e-ISSN: 2615-868X

2. Data about vocabulary mastery by using the instrument is needed to measure the students' vocabulary in the population. The instrument is a particular test that designs to know students' capability in mastering vocabulary in English.

3. Data about students' writing descriptive text in this research is taken from asking students to write an essay a descriptive text on a sheet of paper prepared. Students make the essay appropriate with the theme that the researcher has specified.

\section{Findings and Discussion}

\section{A. The Description of Data}

\section{Data Analysis of Simple Present Verb Mastery $\left(X_{I}\right)$}

Simple Present Verb Mastery as the independent variable $\left(\mathrm{X}_{1}\right)$. The researcher conducted a written test to know the students' simple present verb mastery score: changing the word in the bracket into the correct simple present tense as many as 25 items.

Tabel 1. Description Data of Simple Present Verb Mastery Research Statistics

\begin{tabular}{|c|c|c|}
\hline & Valid & 72 \\
\hline & Missing & 0 \\
\hline \multicolumn{2}{|c|}{ Mean } & 76,72 \\
\hline \multicolumn{2}{|c|}{ Median } & 76,00 \\
\hline \multicolumn{2}{|c|}{ Mode } & $72^{\mathrm{a}}$ \\
\hline \multicolumn{2}{|c|}{ Std. Deviation } & 11,459 \\
\hline \multicolumn{2}{|c|}{ Minimum } & 44 \\
\hline \multicolumn{2}{|c|}{ Maximum } & 100 \\
\hline \multicolumn{2}{|c|}{ Sum } & 5524 \\
\hline
\end{tabular}

From the data above, it can be seen that the total score of the Simple Present Verb test was 5524. Applying SPSS for windows showed that the mean was 76,72 , median was 76.00 , mode was 72 , and standard deviation was 11,459 . The minimum score of simple present verb test score was 44 , and the maximum score was 100. Based on the result statistics above, the mean of Simple Present Verb was 76,72. It means that the students' simple present verb mastery at State Vocational High Schools in Tangerang Regency is pretty high. To clarify the data above, illustrated in the histogram as follows: From the histogram and frequency polygon above, it can be concluded that students' simple present verb mastery at State Vocational High Schools in Tangerang Regency has a normal distribution. 


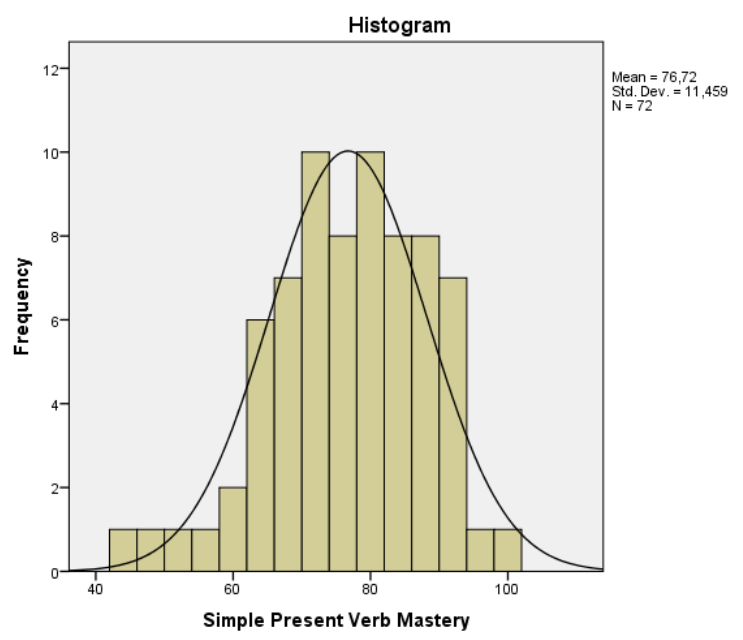

Figure 2. Polygon Histogram of Simple Present Verb Mastery

\section{Data Analysis of Vocabulary Mastery $\left(X_{2}\right)$}

Vocabulary mastery is a score of the ability to understand words of foreign knowledge such as the meaning of words written from the word, the spoken form of the word, the grammatical of the word, and other things related to vocabulary knowledge. To obtain students' data in vocabulary, the test of vocabulary mastery is an objective test in multiple-choice types; the test consists of 25 items. Below is the result of students' simple present verb mastery test:

Tabel 2. Description Data of Vocabulary Mastery Research

Statistics

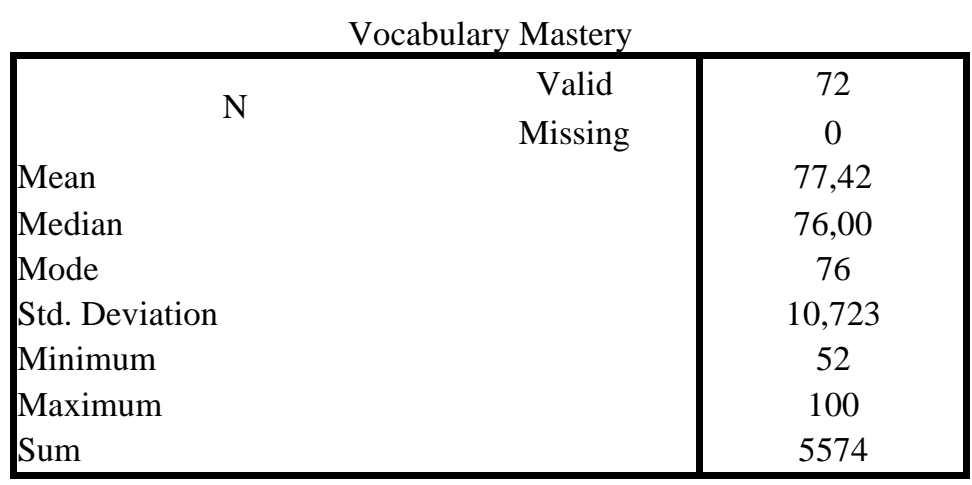

From the data above, it can be seen that the total score of the Vocabulary Mastery test was 5574. Applying SPSS for windows showed that the mean was 77,42, the median was 76,00 , the mode was 76 , and the standard deviation was 10,723. The minimum score of students' writing descriptive text score was 52 , and the maximum score was 100. Based on the result statistics above, the mean of Vocabulary Mastery was 77,42. It means that the student's vocabulary mastery at State Vocational High Schools in Tangerang Regency is pretty high. To clarify the data above, illustrated in the histogram as follows: 


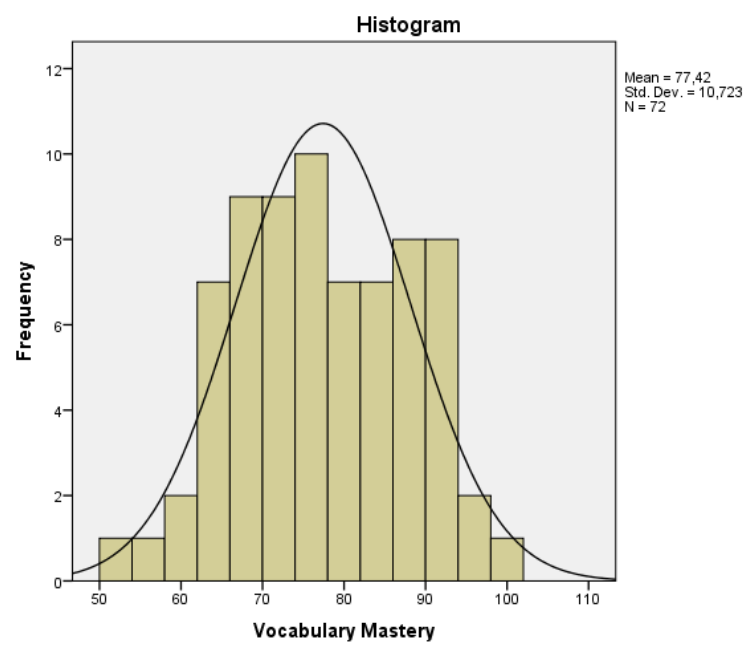

Figure 3. Polygon Histogram of Vocabulary Mastery

From the histogram and frequency polygon above, it can be concluded that students' vocabulary mastery at State Vocational High Schools in Tangerang Regency has a normal distribution.

\section{Data Analysis of Students' Writing Skill in Descriptive Text (Y)}

Tabel 3. Description of Data Research of Student's Writing Skill in Descriptive Text Statistics

Students' Writing Skill in Descriptive Text

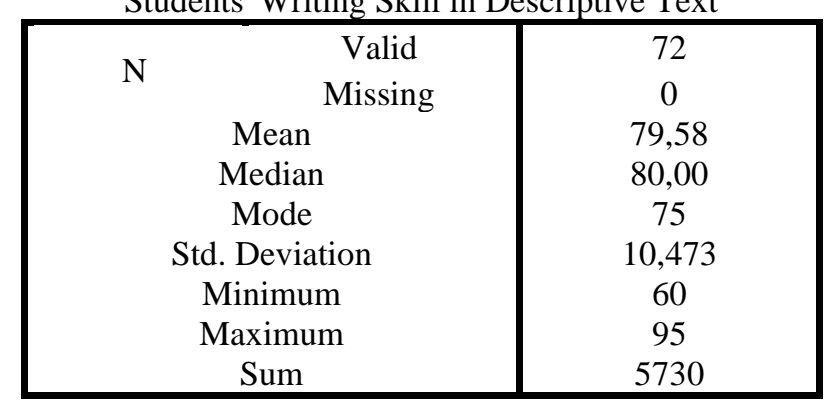

From the data above, it can be seen that the total score of students' writing descriptive text test was 5730. Applying SPSS for windows showed that the mean was 79,58, the median was 80.00 , the mode was 75 , and the standard deviation was 10,473 . The minimum score of students' writing descriptive text score was 60 , and the maximum score was 95 . Based on the results statistics above, the mean of students' writing descriptive text was 79.58. It means that students' writing descriptive text at State Vocational School in Tangerang Regency is relatively high. To clarify the data above, illustrated in the histogram as follows: 


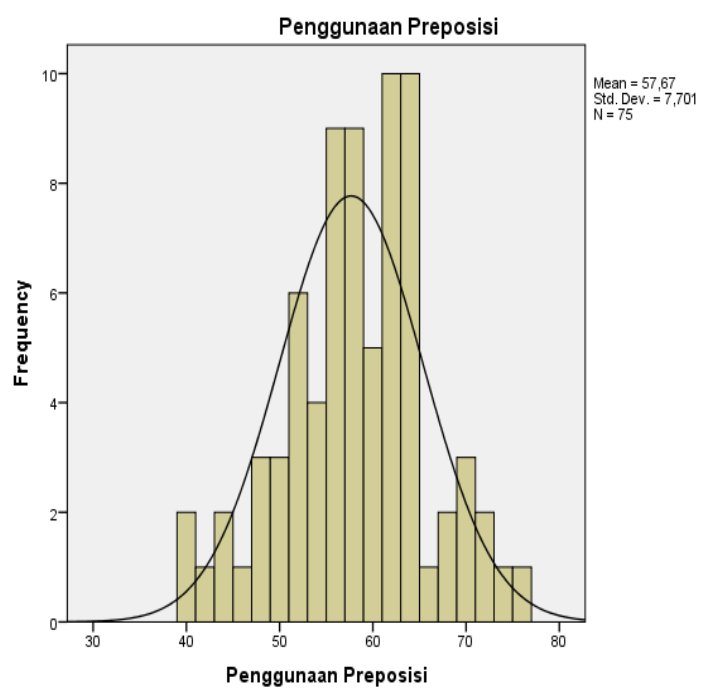

Figure 4. Polygon Histogram of Students' Writing Skill in Descriptive Text

From the histogram and frequency polygon above, it can be concluded that students' writing skill in descriptive Text at State Vocational High Schools in Tangerang Regency has a normal distribution.

\section{B. Analysis of Data Requirement}

\section{Classic Assumption Test}

\section{a. Normality Test Data}

Based on the criteria of normality data, "is p-value sig $>0.05$, so $\mathrm{H}_{0}$ is accepted", which means that the sample has a normal distribution. The value of p-value sig is the number that exists in the sig column inside the output table the normality test calculation from SPSS, and it can be seen from the table:

Table 4. Recapitulation Result of Normality Test One-Sample Kolmogorov-Smirnov Test

\begin{tabular}{|c|c|c|c|c|}
\hline & & $\begin{array}{l}\text { Simple Present } \\
\text { Verb Mastery }\end{array}$ & $\begin{array}{c}\text { Vocabulary } \\
\text { Mastery }\end{array}$ & $\begin{array}{c}\text { Students' } \\
\text { Writing Skill } \\
\text { in } \\
\text { Descriptive } \\
\text { Text }\end{array}$ \\
\hline $\mathrm{N}$ & & 72 & 72 & 72 \\
\hline & Mean & 76,72 & 77,42 & 79,58 \\
\hline Normal Parameters ${ }^{\mathrm{a}, \mathrm{b}}$ & $\begin{array}{c}\text { Std. } \\
\text { Deviation }\end{array}$ & 11,459 & 10,723 & 10,473 \\
\hline & Absolute & ,099 & ,096 & ,128 \\
\hline $\begin{array}{l}\text { Most Extreme } \\
\text { Differences }\end{array}$ & Positive & ,063 & 096 & ,128 \\
\hline & Negative &,- 099 &,- 091 &,- 128 \\
\hline Kolmogorov-Sn & $\operatorname{rnov} \mathrm{Z}$ & 837 & 815 & 1,087 \\
\hline Asymp. Sig. (2 & ailed) & ,485 & ,520 & ,188 \\
\hline
\end{tabular}

a. Test distribution is Normal.

b. Calculated from data.

Based on the result of the normality test using SPSSS, it can be concluded that the sample of writing, simple present verb, and vocabulary mastery in a normal distribution is indicated by all the significance values (Asymp. Sig) is greater than 0,05.

\section{b. Multicollinearity Test}

Multicollinearity aims to test whether the regression model found a perfect correlation between the free variables (independent). A good model regression should not occur a perfect correlation between 
INFERENCE: Journal of English Language Teaching

Vol. 4, No. 1, April - July 2021

p-ISSN: 2615-8671

e-ISSN: 2615-868X

the independent variables. One way to detect multicollinearity is to look at tolerance or Variant Inflation Factor (VIF). If the tolerance is $<0,1$ or VIF $>10$ then occurs multicollinearities.

Table 5. Multicollinearity Test

Coefficients ${ }^{\mathrm{a}}$

\begin{tabular}{|c|c|c|}
\hline \multirow{2}{*}{ Model } & \multicolumn{2}{|c|}{ Collinearity Statistics } \\
\cline { 2 - 3 } & Tolerance & VIF \\
\hline (Constant) & & \\
Simple Present Verb Mastery &, 251 & 3,985 \\
Vocabulary Mastery &, 251 & 3,985 \\
\hline
\end{tabular}

a. Dependent Variable: Students' Writing Skill in Descriptive Text

Multicollinearity test results in the table above is known that the Tolerance 0,251>0,1 or Variant Inflation Factor (VIF) 3,985 < 10. So, it can be stated that there is no multicollinearity between simple present verb mastery and vocabulary mastery in this multiple regression analysis.

\section{c. Test Heteroscedasticity}

Understanding heteroscedasticity is if the error or residual observed do not have a constant variance. Heteroscedasticity condition often occurs in the cross-section data or data derived from some respondents at a specific time. One method for detecting the presence of heteroscedasticity is to create a scatterplot between Standard Residual (ZRESID) and Standardized Predicted Value (Y hat). The picture below showed no change in $\mathrm{E}$ and the $\mathrm{Y}$ hat, then declared no heteroscedasticity in errors (error/residual).

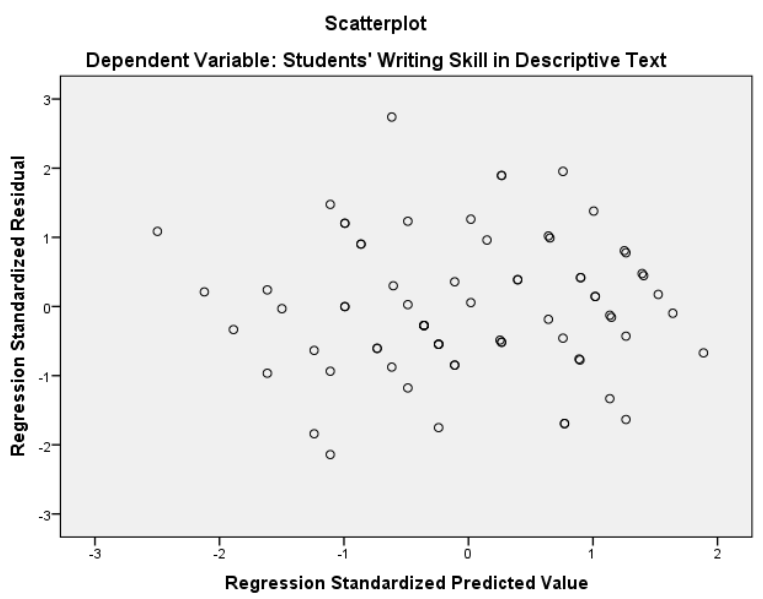

Figure 5. Scatter plot Heteroscedasticity Test

Figure 5 shows that the dots spread randomly and does not form a specific pattern is clear, as well as scattered above and below the number 0 on the axis Y. this indicates that there is no heteroscedasticity in the regression model, so it can be used to predict students' writing skill in descriptive text-based present verb and vocabulary mastery.

d. Normality Error Test 
Table 5. Normality Error Test

One-Sample Kolmogorov-Smirnov Test

\begin{tabular}{|c|c|c|}
\hline & & $\begin{array}{c}\text { Unstandardized } \\
\text { Residual }\end{array}$ \\
\hline \multicolumn{2}{|l|}{$\mathrm{N}$} & 72 \\
\hline \multirow{3}{*}{ Normal Parameters ${ }^{\mathrm{a}, \mathrm{b}}$} & Mean & 0E-7 \\
\hline & Std. Deviation & 4,08852631 \\
\hline & Absolute &, 065 \\
\hline \multirow[t]{2}{*}{ Most Extreme Differences } & Positive &, 065 \\
\hline & Negative &,- 053 \\
\hline \multicolumn{2}{|c|}{ Kolmogorov-Smirnov Z } &, 549 \\
\hline \multicolumn{2}{|c|}{ Asymp. Sig. (2-tailed) } & ,924 \\
\hline
\end{tabular}

a. Test distribution is Normal.

b. Calculated from data.

The table above shows the hypothesis that the distribution of the residuals in this regression analysis follows a normal distribution. This is indicated by the value of $\mathrm{Z}=0,549$ and Sig. $=0,924$ > 0,05 . This means that assumptions or regression analysis requirements are met.

\section{Linearity Test}

Linearity testing in this study used the following hypothesis:

$\mathrm{H}_{0}$ : regression line for the relationship between variable $\mathrm{X}$ and variable $\mathrm{Y}$ is linear.

$\mathrm{H}_{1}$ : the regression line for the relationship between variable $\mathrm{X}$ and variable $\mathrm{Y}$ is not linear.

a. Regression Linearity Simple Present Verb Mastery $\left(X_{1}\right)$ Variable effect towards Students' Writing Skills in Descriptive Text $(Y)$

In this test, the results obtained in table 6 below:

Table 6. The Result of Variable Regression Testing Linearity (Y) towards $\left(\mathrm{X}_{1}\right)$

ANOVA Table

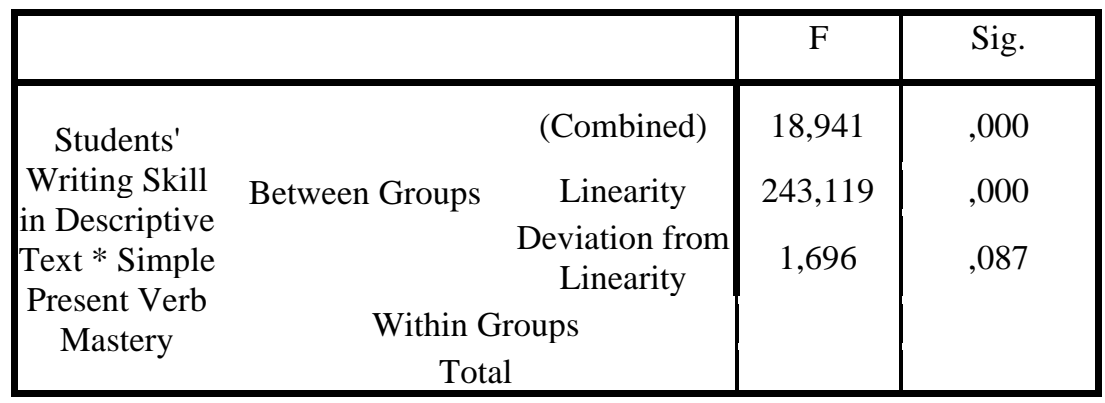

From Table 6 , the value in the sig column. line derivation from linearity with $\mathrm{F}_{0}=1,696$ and Sig. $=0,087>0,05$. It has a sense that the variable present verb mastery towards students' writing skill in the descriptive text has a linear relationship.

b. Regression Linearity Vocabulary Mastery $\left(X_{2}\right)$ Variable effect towards Students' Writing Skills in Descriptive Text $(Y)$

In this test, the results obtained in table 7 below: 
INFERENCE: Journal of English Language Teaching

Vol. 4, No. 1, April - July 2021

p-ISSN: 2615-8671

e-ISSN: 2615-868X

Table 7. The Result of Variable Regression Testing Linearity (Y) towards $\left(\mathrm{X}_{2}\right)$ ANOVA Table

\begin{tabular}{|ccc|c|c|}
\hline & & F & Sig. \\
\hline \multirow{2}{*}{ Students' Writing } & Between & (Combined) & 26,201 &, 000 \\
Skill in Descriptive & Groups & Linearity & 326,168 &, 000 \\
Text * Vocabulary & Deviation from Linearity & 1,203 &, 303 \\
Mastery & Within Groups & & \\
& Total & & \\
\hline
\end{tabular}

The table above shows that the value in the sig column. line derivation from linearity with $\mathrm{F}_{0}=$ 1,203 and Sig. $=0,303>0,05$. It has a sense that the variable vocabulary mastery towards students' writing skill in the descriptive text has a linear relationship.

\section{B. Hypothesis Test}

The hypothesis test is done based on what is written in the last chapter III. The hypothesis test uses SPSS 20 calculations (with multiple linear regression analysis) with the following output:

Table 8. The Results of Correlation Coefficient Calculation of the Effects of Variables X1 and X2 towards Y

Model Summary

\begin{tabular}{|c|c|c|c|c|}
\hline Model & $\mathrm{R}$ & $\mathrm{R}$ Square & $\begin{array}{c}\text { Adjusted R } \\
\text { Square }\end{array}$ & Std. Error of the Estimate \\
\hline 1 &, $921^{\mathrm{a}}$ &, 848 &, 843 & 4,147 \\
\hline
\end{tabular}

a. Predictors: (Constant), Vocabulary Mastery, Simple Present Verb Mastery

Table 9. Recapitulation Table of Results of Calculation of Test of Significance of Regression Coefficient Effect of Variables X1 and X2 towards Y

ANOVA $^{\mathrm{a}}$

\begin{tabular}{|cc|c|c|c|c|c|}
\hline \multicolumn{2}{|c|}{ Model } & Sum of Squares & df & Mean Square & F & Sig. \\
\hline 1 & Regression & 6600,661 & 2 & 3300,330 & 191,873 &, $000^{\mathrm{b}}$ \\
& Residual & 1186,839 & 69 & 17,201 & & \\
& Total & 7787,500 & 71 & & & \\
\hline
\end{tabular}

a. Dependent Variable: Students' Writing Skill in Descriptive Text

b. Predictors: (Constant), Vocabulary Mastery, Simple Present Verb Mastery

Table 10. Recapitulation Table of Results of Calculation of Regression Line Equations Effect of Variables X1 and X2 towards Y

Coefficients $^{\mathrm{a}}$

\begin{tabular}{|c|c|c|c|c|c|}
\hline \multirow[t]{2}{*}{ Model } & \multicolumn{2}{|c|}{ Unstandardized Coefficients } & \multirow{2}{*}{$\begin{array}{c}\begin{array}{c}\text { Standardized } \\
\text { Coefficients }\end{array} \\
\text { Beta }\end{array}$} & \multirow[t]{2}{*}{$\mathrm{t}$} & \multirow[t]{2}{*}{ Sig. } \\
\hline & B & Std. Error & & & \\
\hline (Constant) & 9,585 & 3,614 & & 2,652 &, 010 \\
\hline $1 \begin{array}{c}\text { Simple Present Verb } \\
\text { Mastery }\end{array}$ & ,312 & ,086 & ,342 & 3,644 & ,001 \\
\hline Vocabulary Mastery & ,595 & 092 & 609 & 6,488 &, 000 \\
\hline
\end{tabular}

a. Dependent Variable: Students' Writing Skill in Descriptive Text 
The statistical hypothesis is as follows:

1. The Effect of Simple Present Verb Mastery $\left(X_{1}\right)$ and Vocabulary Mastery $\left(X_{2}\right)$ Jointly toward Students' Writing Skill in Descriptive Text (Y)

The hypotheses of this influence are:

$\mathrm{H}_{0}: \beta_{1}=0$ and $\beta_{2}=0$

$\mathrm{H}_{1:} \beta_{1} \neq 0$ and $\beta_{2} \neq 0$

Meaning:

$\mathrm{H}_{0}$ : There is no significant effect between simple present verb $\left(\mathrm{X}_{1}\right)$ and vocabulary mastery $\left(\mathrm{X}_{2}\right)$ jointly toward students' writing skill in descriptive Text (Y).

$\mathrm{H}_{1}$ : There is a significant effect between simple present verb $\left(\mathrm{X}_{1}\right)$ and vocabulary mastery $\left(\mathrm{X}_{2}\right)$ jointly toward students' writing skill in descriptive Text (Y).

From Table 10 above, it can be seen that the multiple correlation coefficient influences the simple variable present verb $\left(\mathrm{X}_{1}\right)$ and Vocabulary Mastery $\left(\mathrm{X}_{2}\right)$ jointly towards Students' Writing Skill in Descriptive Text (Y) is 0.921. From these calculations, it was found that the correlation coefficient was significant. In other words that there was a significant effect of the simple variable Present Verb $\left(\mathrm{X}_{1}\right)$ and Vocabulary Mastery $\left(\mathrm{X}_{2}\right)$ jointly toward the Students' Writing Skills in Descriptive Text. The determination coefficient of $84,4 \%$ shows that the contribution of Simple Present Verb Mastery $\left(\mathrm{X}_{1}\right)$ and Vocabulary Mastery $\left(\mathrm{X}_{2}\right)$ jointly towards Students' Writing Skill in Descriptive Text (Y) is 84,8\%, and $15,2 \%$ due to the influence of other factors.

While for hypothesis testing through regression analysis shown in Table 9 and Table 10. Table 9 shows $Y$ can express the multiple regression lines $=9,585+0,312 \mathrm{X}_{1}+0,595 \mathrm{X}_{2}$. This means that each increase in one score of the simple present verb variable and vocabulary mastery contributes $0,312 \mathrm{X}_{1}$ and 0,595 by $\mathrm{X}_{2}$ to the variable Students' Writing Skill in Descriptive Text.

While testing the significance of the regression line is to show the calculation results in table 8 . According to the existing provisions, the criteria for the significance of the regression are "If Sig < 0,05 then $\mathrm{H}_{0}$ is rejected" or "if $\mathrm{F}$ observe $>\mathrm{F}$ table, then $\mathrm{H}_{0}$ is rejected, it means that the regression coefficient is significant, in other words, there is a significant influence of the independent variables $X_{1}$ and $X_{2}$ toward the dependent variable Y. Sig value is the number listed in the Sig column in table 4.8, the calculated $\mathrm{F}_{\text {observe }}$ is the number listed in column $\mathrm{F}$ in table 4.8. While the $\mathrm{F}_{\text {observe }}$ of the add-table is the distribution table $\mathrm{F}$ for the real level of $5 \%$ with the numerator $(K)=2$ and the denominator degree $(n-k-1)=69$, where $\mathrm{n}$ is the number of respondents, and $\mathrm{k}$ is the number of independent variables.

From Table 8, it can be stated that there are any significant effects of Simple Present Verb and Vocabulary Mastery jointly towards Students' Writing Skills in Descriptive Text. The acquisition of sig proves this. $0,000<0.05$ and $\mathrm{F}_{\text {observe }}=191,873$. Then $\mathrm{H}_{0}$ is rejected, which means that the regression coefficient is significant, in other words, that there is a significant effect between the independent variables Simple Present Verb $\left(\mathrm{X}_{1}\right)$ and Vocabulary Mastery $\left(\mathrm{X}_{2}\right)$ jointly toward the dependent variable Students' Writing Skill in Descriptive Text (Y).

From the results of the correlation and regression tests, it can be concluded that there is a significant influence of the independent variable Simple Present Verb $\left(\mathrm{X}_{1}\right)$ and Vocabulary Mastery $\left(\mathrm{X}_{2}\right)$ jointly toward the dependent variable Students' Writing Skill in Descriptive Text (Y).

\section{The Effect of Simple Present Verb Mastery $\left(X_{1}\right)$ towards Students' Writing Skill in} Descriptive Text (Y)

$\mathrm{H}_{0}: \beta_{1}=0$

$\mathrm{H}_{1}: \beta_{1} \neq 0$

Means:

$\mathrm{H}_{0}$ : There is no significant effect between simple present verb master toward students' writing skill in descriptive text.

$\mathrm{H}_{1}$ : There is a significant effect between simple present verb master toward students' writing skill in descriptive text.

To prove this hypothesis is to pay attention to the values / numbers listed in column $\mathrm{t}$ or Sig column for the Simple Present Verb Mastery $\left(\mathrm{X}_{1}\right)$ row in Table 8; according to the existing provisions, 
INFERENCE: Journal of English Language Teaching

Vol. 4, No. 1, April - July 2021

p-ISSN: 2615-8671

e-ISSN: 2615-868X

the criteria for the significance of the regression are "if Sig $<0.05$ then $\mathrm{H}_{0}$ is rejected" which means that there is a significant influence of the independent variable $\mathrm{X}_{1}$ on the dependent variable $\mathrm{Y}$ and vice versa.

From Table 8, it appears that the value of Sig $=0.001<0.05$ and $t_{\text {observe }}=3,664$ then $\mathrm{H}_{0}$ is accepted, it means that there is a significant effect of Simple Present Verb Mastery on Students' writing skill in descriptive text. The formula can express the variable contribution Simple present verb mastery towards students' writing skill in descriptive text:

$$
\begin{gathered}
\mathrm{KD}=\text { Value } \beta_{\mathrm{x} 1 \mathrm{y}} \times \mathrm{x} \text { The Value Correlation Pasial }\left(\mathrm{r}_{\mathrm{x} 1 \mathrm{y}}\right) \times 100 \% \\
\mathrm{KD}=0,342 \times 0,869 \times 100 \%=29,72 \%
\end{gathered}
$$

The calculation above can be stated that the contribution of simple present verb mastery in improving student's writing skills in the descriptive text is $29,72 \%$.

3. The Effect of Vocabulary Mastery $\left(\mathrm{X}_{2}\right)$ towards Students' Writing Skill in Descriptive Text

(Y)

$\mathrm{H}_{0}: \beta_{2}=0$

$\mathrm{H}_{1}: \beta_{2} \neq 0$

Means:

$\mathrm{H}_{0}$ : There is no significant effect between vocabulary mastery towards students' writing skills in descriptive text.

$\mathrm{H}_{1}$ : There is a significant effect between vocabulary mastery towards students' writing skills in descriptive text.

To prove this hypothesis, pay attention to the values/ numbers listed in column t or Sig column for the Vocabulary Mastery $\left(\mathrm{X}_{2}\right)$ row in table 8 . According to the existing provisions, the criteria for the significance of the regression are "if $\mathrm{Sig}<0.05$ then $\mathrm{H}_{0}$ is rejected," which means that there is a significant effect between the independent variable $\mathrm{X}_{2}$ towards the dependent variable $\mathrm{Y}$ and vice versa.

From table 8, it appears that the value of $\mathrm{Sig}=0.000<0.05$ and $\mathrm{t}_{\text {observe }}=6,488$ then $\mathrm{H}_{0}$ is rejected. There is a significant effect of Vocabulary Mastery on Students' writing skill in descriptive text. The test results show a significant effect between the independent variable $\mathrm{X}_{2}$ (Vocabulary Mastery) towards the dependent variable Y (Students' Writing Skill in Descriptive Text). The formula can express the variable contribution vocabulary mastery towards students' writing skill in descriptive text:

$$
\begin{gathered}
\mathrm{KD}=\text { Value } \beta_{\mathrm{x} 2 \mathrm{y}} \times \text { The Value Correlation Pasial }\left(\mathrm{r}_{\mathrm{x} 2 \mathrm{y}}\right) \times 100 \% \\
\mathrm{KD}=0,609 \times 0,905 \times 100 \%=55,11 \%
\end{gathered}
$$

The calculation above can be stated that simple present verb mastery in improving student's writing skills in writing the descriptive text is $55,11 \%$.

\section{Conclusions}

There are significant effects of simple present verb and vocabulary mastery on students' writing skills in descriptive Text at State Vocational High Schools in Tangerang Regency. It is proved by the result value Sig $=0,000<0,05$ and $F_{0}=191,873$. There is a significant effect of simple present verb mastery towards students' writing skill in descriptive Text at State Vocational High Schools in Tangerang Regency. It is proved by the result value $\operatorname{Sig}=0,001<0,05$ and $t_{0}=3,644$. There is a significant effect of vocabulary mastery towards students' writing skill in descriptive Text at State Vocational High Schools in Tangerang Regency. It is proved by the result value $\mathrm{Sig}=0,000<0,05$ and $\mathrm{t}_{0}=6,488$.

\section{References}

Alexander, L. G. (1998). Longman English Grammar Practice for Intermediate Students. England: Longman. 
Ali, A. F. R. (2007). Fundamental of English Grammar A Practice Guide. Yogyakarta: Pustaka Widyatama.

Allen, Robert. (2000). The New Penguin English Dictionary. London: Penguin Books.

Ansell, M. (2000). Free English Grammar. www.seyfihoca.com

Al Qothani, M. (2015). The Importance of Vocabulary in Language Learning and How to Be Taught. International Journal of Teaching and Education. 111(3): 25.

Azar, B. S. (1941). Basic English Grammar $2^{\text {nd }}$ Edition. New York: Longman Group.

Black, K. (2010) "Business Statistics: Contemporary Decision Making" $6^{\text {th }}$ edition, John Wiley \& Sons

Brown, H. Douglas.2004. Language Assessment Principles and Classroom Practices. USA: Longman.

Brown, H. D. (2000). Principles of Language Learning and Teaching. USA: San Francisco State.

Celce-Murcia, M. \& Olshtain, E. (2000). Discourse and Context in Language Teaching. USA: Cambridge University Press.

Creswell, J. W. (2009). Research Design, Qualitative, Quantitative, and Mixed Methods Approach $3^{\text {rd }}$ Edition. USA: Sage.

Eastwood, J. (2002). Practice Grammar with Answer $2^{\text {nd }}$ Edition. New York: Oxford University Press.

Folse, K.S., Vokoun, A.M., Solomon, E.V. (2010). Great Paragraphs Third Edition. USA: Heinle Cengage Learning.

Fraenkel, J. R., \& Wallen, N. E. (2009). How to Design and Evaluate Research in Education $7^{\text {th }}$ Edition. New York: Mc. Graw Hill.

Hastuti, S. D. S. \& Widyantoro, A. (2015). The Influence of Vocabulary and Grammar Mastery on The Students' Writing Skill at Yogyakarta State University. Bahasa, Sastra dan Terjemahan. 1(1) : 74.

Hayland, K. (2009). Second Language Writing. Cambridge: Cambridge University Press.

Jabbari, M. J. (2013). Time and Tense in Language. International Journal of Linguistics ISSN 1948-5425. 5(5): 245.

Jackson, H. (2002). Grammar and Vocabulary. London: Routledge.

Jackson, H. \& Amuela, Z. E. (2000). Words, Meaning, And Vocabulary. An Introduction to Modern English Lexicology. London and New York: Cassell.

Knapp, P., \& Watkins, M. (2005). Genre, Text, Grammar: Technologies for Teaching and Assessing Writing. Sydney: University of New South Wales Press Ltd.

Kurniawan, I., \& Seprizanna. (2016). An Analysis of Students' Ability in Using Subject-Verb Agreement. English Education: Jurnal TBI P- ISSN 2086-6003. 9(2): 332.

Larsen-Freeman, D. (1986). Techniques and Principles in Language Teaching. Oxford: Oxford University Press.

Lester, M. (2012). English Verb Tense Up Close. New York: Mc. Graw Hill.

Lester, M., Franklin, D., \& Yokota, T. (2009). The Big Book of English Verbs. New York: Mc. Graw Hill.

Martha. (2010). Definition of Vocabulary Mastery. Accessed on $9^{\text {th }}$ January 2020 (http://id.scribd.com/doc/18475644/Vocabulary-Mastery)

Martin, J. E. (2020). Reinventing Crediting for Competency-Based Education. New York: Routledge.

Mawardi, I., Basri, H., \& Waris, A. (2014). Improving The Ability in Writing Descriptive Text through Guided-Questions Technique. E-Journal of English Language Teaching Society (ELTS). 2 (1): 2.

Monalisa, \& Hafizh, M.A. Wordle (World Cloud) Prediction Activity at Junior High School. Online at http://ejournal.unp.ac.id/(accessed on 10/01/2016).

Napitupulu, D. (2014). Studi Validitas dan Reliabilitas Faktor Sukses Implementasi E-Goverenment Berdasarkan Pendekatan Kappa. Jurnal Sistem Informasi (Journal of Information Systems). 10(2): 72-73.

Nation, I. S. P. 2001. Learning Vocabulary In Another Language. New York: Cambridge University Press.

O'Malley, J.M. (1996). Authentic Assessment for English Language Learners: Practical Approaches for Teachers. Massachusetts: Addison Wesley Publishing Company.

Pardiyono. (2007). Pasti Bisa! Teaching Genre Based Writing. Yogyakarta: Pennsylvania: International Textbook Company.

Poedjosoedarmo, D. (2002). The Grammar of English: Morphology and Syntax for English Teachers in Southeast Asia. Singapore: Prentice-Hall. 
INFERENCE: Journal of English Language Teaching

Vol. 4, No. 1, April - July 2021

p-ISSN: 2615-8671

e-ISSN: 2615-868X

Richard, J. C. (2002). 30 Years of TEFL/TESL a Personal Reflection. Singapore: Seameo Regional Language Centre.

Ruminda. (2016). Semantic Categories of Reporting Verbs in Online News Articles. Jurnal al- Tsaqafa. 13(1): 22.

Setiarini, R. (2012). Penanaman Pengetahuan Verb dalam Bahasa Inggris untuk Pengajaran Writing. @ Pengembangan Pendidikan. 9(2): 411-422.

Siahaan, S. (2007). Issues in Linguistics $1^{\text {st }}$ Edition. Yogyakarta: Graha Ilmu.

Siswoyo. (2016). Students' Error in Using Simple Present Tense Mastery, STKIP Muhammadiyah Pringsewu Lampung. Jurnal Tadris Bahasa Inggris. 9(2): 465.

Saunders, M., Lewis, P. \& Thornhill, A. (2012) "Research Methods for Business Students" $6^{\text {th }}$ edition, Pearson Education Limited

Sugiyono. (2015). Metode Penelitian Kombinasi (Mix Methods). Bandung: Alfabeta. 